\title{
JURNAL MANAJEMEN BISNIS DAN KEWIRAUSAHAAN
}

Terbit enam kali dalam setahun. Berisi tulisan yang diangkat dari hasil penelitian di bidang Ilmu Manajemen dan Kewirausahaan.

\section{Ketua Dewan Penyunting}

Prof. Ir. Carunia Mulya Firdausy, MA, Ph.D - Universitas Tarumanagara

\section{Wakil Ketua Dewan Penyunting}

Dr. Eko Harry Susanto - Universitas Tarumanagara

\author{
Anggota Dewan Penyunting \\ Dr. Ir. Agus Zainul Arifin, MM - Universitas Tarumanagara \\ Dr. Eddy Supriyatna MZ, M.HUM - Universitas Tarumanagara \\ Dr. Anas Lutfi, MM, MKN - Universitas Indonesia \\ Dr. Hardius Usman, M.Si - Universitas Indonesia \\ Dr. Indra Widjaja, SE, MM - Universitas Tarumanagara \\ Dr. Hetty Karunia Tunjung Sari - Universitas Tarumanagara
}

\author{
Sekretariat \\ Maria Benedicta, SE \\ Margaretha Hillary, S.Ds, MM
}

Alamat Penyunting dan Tata Usaha: Program Studi MM Untar, Kampus 1, Gedung Utama, Lantai 14, Jl. Let. Jen. S. Parman No. 1 Grogol, Jakarta 11440. Telp. (62-21) 5655806 dan Fax. (62-21) 5655808. Email: mm@untar.ac.id 


\section{JURNAL MANAJEMEN BISNIS \& KEWIRAUSAHAAN}

September 2019, Volume 3, No. 5

e-ISSN 2598-0289

Halaman 1-86

Pengaruh Celebrity Endorser, Shopping Orientation, Online Trust, dan Prior Online Purchase Experience Terhadap Minat Beli Konsumen Toko Online Elevenia di DKI Jakarta

Deasi Arindani dan Riris Loisa

Pengaruh Promosi Penjualan, Daya Tarik Iklan Internet, dan Kualitas WebsiteTerhadap Pembelian Impulsif Maria Fernanda

Pengaruh Current Ratio, Return On Asset, Return On Equity, Debt To Equity Ratio, Total Turnover Asset, dan Dividend Policy Terhadap Harga Saham

Margaret Calista dan Indra Widjaja

Pengaruh Current Ratio (CR), Debt To Equity Ratio (DER), Net Profit Margin (NPM) dan Earning Per Share (EPS) Terhadap Harga Saham Perusahaan Konstruksi \& Bangunan yang Terdaftar di Bursa Efek Indonesia (BEI) Periode 2013-2017

Jenni Suryana dan Indra Widjaja

Pengaruh Merek Terhadap Kepuasan Pelanggan (Studi Kasus : Furniture Impor B\&B Italia) Margaretha Hillary

Strategi PT. Ciracasindo Perdana dalam Persaingan Usaha dengan Metode Quantitative Strategic Planning Matrix dan SWOT Jeremy Jonathan

Peran Brand Attractiveness Sebagai Variabel Intervening pada Brand Distinctiveness, Brand Prestige, Brand Sosial Benefit, dan Memorable Brand Experience Terhadap Customer Brand Identification

Kris Jati Kesuma JP dan Hetty Karunia Tunjung Sari

Analisis Penerapan Program Tax Amnesty Di Indonesia

Valdi Sayoga

Analisis Pengaruh Transformasi Digital dan Pola Perilaku Konsumen

Terhadap Perubahan Bisnis Model Perusahaan di Indonesia

Ricky Oktavenus

Pengaruh Brand Image, Persepsi Harga dan Kualitas Pelayanan Terhadap Kepuasan Pelanggan Alex Witama

Pengaruh Brand Image, Service Quality, dan Customer Relationship Management

Terhadap Customer Loyalty

Samuel Hendy dan Keni

Analisis SWOT dalam Menetapkan Strategi Menjalankan BPJS Kesehatan pada Mitra Keluarga Kalideres Martinus Limaku

Efek Profitabilitas dan Ukuran Perusahaan Terhadap Nilai Perusahaan dengan Pengungkapan Corporate Social Responsibility Sebagai Variabel Mediasi pada Perusahaan Konstruksi yang Terdaftar di Bursa Efek Indonesia Tahun 2014-2016

Robert

Pengaruh Inflasi dan Pertumbuhan Ekonomi Terhadap Laba Bank Umum yang Terdaftar Di BEI Effendy Sutejo

Pengaruh Gaya Kepemimpinan, Kepuasan Kerja dan Motivasi

Terhadap Kinerja Karyawan Top Yummy di Jakarta

Rayen Eduard Wijaya 